\title{
HYPNOBRITHING DALAM UPAYA MENURUNKAN KECEMASAN PADA IBU HAMIL PRIMIGRAVIDA DI KLINIK PRATAMA ANNUR KARANGANYAR
}

\author{
Anik Sulistiyanti ${ }^{1, *}$, Siti Farida ${ }^{2}$ \\ ${ }^{1,2}$ Universitas Duta Bangsa Surakarta \\ ${ }^{1}$ anik_sulis@udb.ac.id*
}

\begin{abstract}
Abstrak
Latar belakang : Kehamilan merupakan anugerah bagi setiap wanita. Permasalahan yang muncul pada saat kehamilan menimbulkan gangguan fisik maupun psikis seperti rasa khawatir, stres dan cemas menjadi seorang ibu. Keluhan saat kehamilan seperti Hyperemesis Gravidarum (muntah berlebihan), Rasa mual, pusing, dan badan lemas yang sering terjadi ketika hamil, Kecemasan dan ketakutan saat menghadapi proses persalinan. Rasa ketakutan dan kekhawatiran ibu hamil terekam dalam pikiran bawah sadar para ibu hamil dapat menggunakan metode hypnobirthing dilakukan mulai masa kehamilan dapat membantu menurunkan tingkat kecemasan.

Tujuan : untuk mengetahui pengaruh hypnobirthing dalam menurunkan tingkat kecemasan pada ibu hamil primigravida di Klinik pratama Annur Karanganyar. Metode : Sampel penelitian adalah 30 ibu hamil primigravida trimester III. Jenis penelitian dengan quasi experiment menggunakan rancangan Pretest-Posttest one group design. Variabel Bebas adalah Hypnobirthing dan variabel terikat adalah kecemasan pada ibu hamil. Instrumen pengukuran kecemasan menggunakan HRSA (Hamillton Rating Scale For Anxiety) dan uji statistik Independent sample t-test. Hasil : tingkat kecemasan ibu hamil primigravida sebelum dilakukan hipnobirthing didapatkan 19 responden $(63,3 \%)$ mengalami kecemasan ringan, 11 responden $(36,7 \%)$ mengalami kecemasan sedang., tingkat kecemasan sesudah dilakukan hipnobirthing didapatkan 14 responden $(46,7 \%)$ mengalami kecemasan ringan, 3 responden (10\%) mengalami kecemasan sedang dan 13 responden $(43,3 \%)$ tidak mengalami kecemasan. Hasil Uji Statistik Independent sample t-test menunjukkan $\mathrm{p}$ value (sig 2 tailed $)=0,000$.
\end{abstract}

Simpulan : Ada pengaruh hypnobirthing dalam menurunkan tingkat kecemasan pada ibu hamil primigravida di Klinik pratama Annur Karanganyar

Kata Kunci : Hypnobirthing; Kecemasan; Primigravida

HYPNOBRITHING EFFORTS TO REDUCE ANXIETY PRIMIGRAVIDA PREGNANT MOTHERS IN ANNUR PRIMARY CLINIC, KARANGANYAR DISTRICT

\section{Abstract}

Background Of Study : Pregnancy is a gift for every woman. Problems that arise during pregnancy cause physical and psychological disorders such as worry, stress 
and anxiety to be a mother. Complaints during pregnancy such as Hyperemesis Gravidarum (Excessive vomiting), nausea, dizziness and weakness in the body that often occurs during pregnancy, anxiety and fear when facing labor. Fears and worries of pregnant women recorded in the subconscious mind of pregnant women can use the hypnobirthing method carried out starting during pregnancy can help reduce anxiety levels.

Purpose of Study: to find out the effect of hypnobirthing in reducing anxiety levels in primigravida pregnant women in Annur Primary Clinic Karanganyar District.

Method Of Study : the study sample was 30 trimester III primigravida pregnant women. This type of research is quasi experiment using the Pretest-Posttest one group design. The independent variable is Hypnobirthing and the dependent variable is anxiety in pregnant women. Anxiety measurement instrument uses HRSA (Hamillton Rating Scale for Anxiety) and Independent sample t-test statistical tests.

Outcome : anxiety levels of primigravida pregnant women before hypnobirthing was obtained 19 respondents (63.3\%) experienced mild anxiety, 11 respondents $(36.7 \%)$ experienced moderate anxiety., the level of anxiety after hypnobirthing was obtained 14 respondents (46.7\%) experienced anxiety mild, 3 respondents (10\%) experienced moderate anxiety and 13 respondents (43.3\%) did not experience anxiety. Statistical Test Results Independent sample t-test showed p value (sig 2 tailed) $=0,000$.

Conclusion : there is hypnobirthing effect in reducing anxiety levels in primigravida pregnant women in Annur Primary Clinic, Karanganyar District.

Keywords : Hypnobirthing; anxiety; Primigravida

\section{PENDAHULUAN}

Kehamilan merupakan anugerah bagi setiap wanita. Permasalahan yang muncul pada saat kehamilan menimbulkan gangguan fisik maupun psikis seperti rasa khawatir, stres dan cemas menjadi seorang ibu dapat disebabkan karena adanya peningkatan hormone estrogen dan progesteron pada ibu hamil cenderung menciptakan ketidakstabilan tubuh dan pikiran, sehingga wanita yang sedang hamil menjadi lebih mudah cemas, terjadi kepanikan, mudah tersinggung, jauh lebih sensitif, mudah terpengaruh, mudah marah dan tidak rasional (Marliana, 2016)

Menurut Detiana, 2010 dalam jurnal Adina tahun 2019 menyatakan bahwa kehamilan pertama kali bagi seorang calon ibu merupakan kehidupan baru, dengan adanya perubahan fisik dan psikis menyebabkan masalah psikologis. Tahap trimester pertama ibu masih merasakan penyesuaian dari kondisi kehamilannya, umumnya ibu mengalami morning sickness. Tahap Trimester kedua ibu sudah mulai nyaman dengan kondisi kehamilannya dan pada tahap trimester ketiga mulai timbul kecemasan pada ibu dalam menghadapi persalinannya. Penyebab utama timbulnya gangguan psikis pada periode ini adalah perasaan takut menghadapi kehamilan maupun persalinan (Adina, 2019)

Primigravida merupakan wanita yang pertama kali hamil mengalami keluhan kekhawatiran, kecemasan dan ketakutan selama hamil, keluhan saat kehamilan seperti Hyperemesis Gravidarum (muntah berlebihan), Rasa mual, pusing, dan 
badan lemas yang sering terjadi ketika hamil, Kecemasan dan ketakutan saat menghadapi proses persalinan, Kejadian Persalinan Prematur dan Bayi Baru Lahir Rendah (BBLR), Persalinan Lama, Kejadian Post Partum Blues atau Baby blues setelah melahirkan (Utami, 2011)

Rasa ketakutan dan kekhawatiran ibu hamil terekam dalam pikiran bawah sadar para ibu hamil dapat menggunakan metode hypnobirthing dilakukan mulai masa kehamilan dapat membantu menurunkan tingkat kecemasan dan dikembangkan berdasarkan keyakinan bahwa dengan persiapan persalinan holistik/ menyeluruh (body, mind, and spirit), klien dan pendamping dapat melalui pengalaman persalinan yang aman, nyaman dan memuaskan, jauh dari rasa takut dan cemas yang menimbulkan ketegangan dan rasa sakit. Hypnobirthing bekerja berdasarkan kekuatan sugesti dan visualisasi untuk menenangkan tubuh, memandu pikiran serta mengendalikan nafas klien. Sehingga klien dapat meminimalkan kecemasan, rasa trauma dan dapat menjalani masa kehamilan dengan nyaman dan bebas keluhan (Aprilia, 2013).

Berdasarkan studi pendahuluan dari hasil wawancara yang dilakukan di Klinik Pratama Annur Karanganyar terhadap 10 ibu hamil, didapatkan 9 (90\%) ibu hamil primigravida mengalami ketakutan pada kehamilan trimester 3 karena baru pertama kali hamil, khawatir terhadap kemungkinan komplikasi saat kehamilan serta mengkhawatirkan terhadap kesehatan ibu hamil dan kesehatan janinnya, mengalami keluhan terhadap kekhawatiran yang mereka rasakan tentang kemungkinan adanya kesulitan persalinan yang akan dihadapinya. Hanya 1 (10\%) ibu hamil primigravida yang tidak mengalami kecemasan.

Tujuan penelitian ini adalah untuk mengetahui pengaruh hypnobirthing dalam menurunkan tingkat kecemasan pada ibu hamil primigravida di Klinik pratama Annur Karanganyar.

Berdasarkan latar belakang dan studi pendahuluan diatas, maka penulis tertarik untuk melakukan penelitian yang berjudul "Hypnobrithing dalam upaya menurunkan kecemasan pada ibu hamil primigravida di Klinik Pratama Annur Karanganyar".

\section{METODE}

Penelitian dilakukan di Klinik Pratama Annur Karanganyar pada bulan Agustus sampai November 2019. Populasi dalam penelitian ini adalah seluruh ibu hamil primigravida di Klinik Pratama Annur Karanganyar. Sampel penelitian adalah 30 ibu hamil primigravida trimester III di Klinik Pratama Annur Karanganyar dengan teknik purposive sampling. Jenis penelitian menggunakan quasi experiment dengan rancangan Pretest-Posttest one group design. Variabel Bebas adalah Hypnobirthing dan variabel terikat adalah kecemasan pada ibu hamil.

Instrumen pengukuran tingkat kecemasan sebelum dan sesudah intervensi dengan menggunakan HRS-A (Hamillton Rating Scale For Anxiety) dengan skor pengukuran kecemasan yaitu Skor kurang dari 14 = tidak ada kecemasan, Skor 14$20=$ kecemasan ringan, Skor 21-27 = kecemasan sedang, Skor 28-41 = kecemasan berat, dan Skor 42-56 = kondisi panik. Teknik pengolahan data menggunakan analisis data univariat dan uji statistik Independent sample t-test 


\section{HASIL DAN PEMBAHASAN}

\section{Karakteristik Responden}

a. Distribusi Frekuensi Responden berdasarkan Usia

Tabel 1. Distribusi Frekuensi Responden berdasarkan Usia

\begin{tabular}{lccc}
\hline & Usia & Frekuensi & Persentase \\
\hline $21-25$ tahun & 19 & $63,3 \%$ \\
$26-30$ tahun & 11 & $36,7 \%$ \\
\hline Jumlah & 30 & $100 \%$ \\
\hline
\end{tabular}

Tabel 1 menunjukkan bahwa usia ibu hamil sebagian besar antara 21-25 tahun sejumlah 19 orang dan usia 26-30 tahun sejumlah 11 orang.

b. Distribusi Frekuensi Responden berdasarkan Pendidikan

Tabel 2. Distribusi Frekuensi Responden berdasarkan Pendidikan

\begin{tabular}{|c|c|c|}
\hline Pendidikan & Frekuensi & Persentase \\
\hline SMA & 28 & $93,3 \%$ \\
\hline PT & 2 & $6,7 \%$ \\
\hline Jumlah & 30 & $100 \%$ \\
\hline
\end{tabular}

Tabel 2 menunjukkan bahwa pendidikan ibu hamil sebagian besar antara Sekolah Menengah Atas (SMA) sejumlah 28 orang dan pendidikan Perguruan Tinggi (PT) sejumlah 2 orang.

c. Distribusi Frekuensi Responden berdasarkan Pekerjaan

Tabel 3. Distribusi Frekuensi Responden berdasarkan Pekerjaan

\begin{tabular}{|c|c|c|}
\hline Pekerjaan & Frekuensi & Persentase \\
\hline IRT & 19 & $63,3 \%$ \\
\hline Karyawan swasta & 7 & $23,3 \%$ \\
\hline Pedagang & 4 & $13,3 \%$ \\
\hline Jumlah & 30 & $100 \%$ \\
\hline
\end{tabular}

Tabel 3 menunjukkan bahwa pekerjaan ibu hamil sebagian besar sebagai Ibu Rumah Tangga (IRT) sejumlah 19 orang, 7 orang bekerja sebagai karyawan swasta dan bekerja sebagai pedagang sejumlah 4 orang.

d. Distribusi Frekuensi Responden berdasarkan Usia Kehamilan

Tabel 4. Distribusi Frekuensi Responden berdasarkan Usia Kehamilan

\begin{tabular}{lcc}
\hline Umur Kehamilan & Frekuensi & Persentase \\
\hline 28 Minggu & 3 & $10,0 \%$ \\
29 Minggu & 3 & $10,0 \%$ \\
30 Minggu & 5 & $16,7 \%$ \\
31 Minggu & 4 & $13,3 \%$
\end{tabular}




\begin{tabular}{lcc}
32 Minggu & 5 & $16,7 \%$ \\
33 Minggu & 1 & $3,3 \%$ \\
34 Minggu & 1 & $3,3 \%$ \\
35 Minggu & 5 & $16,7 \%$ \\
36 Minggu & 2 & $6,7 \%$ \\
37 Minggu & 1 & $3,3 \%$ \\
\hline Jumlah & 30 & $100,0 \%$ \\
\hline
\end{tabular}

Tabel 4 menunjukkan bahwa dari 30 responden usia kehamilan antara 28 minggu sampai 37 minggu dan dalam masa trimester ketiga.

e. Distribusi Frekuensi Responden berdasarkan Kunjungan Kehamilan

Tabel 5. Distribusi Frekuensi Responden berdasarkan Kunjungan Kehamilan

\begin{tabular}{lccc}
\hline & Kunjungan & Frekuensi & Persentase \\
\hline $1-5$ kali & 4 & $13,3 \%$ \\
$6-10$ kali & 24 & $80,0 \%$ \\
$11-15$ kali & 2 & $6,7 \%$ \\
\hline Jumlah & 30 & $100,0 \%$
\end{tabular}

Tabel 5 menunjukkan bahwa ibu hamil primigravida melaksanakan kunjungan kehamilan 1 sampai 5 kali sejumlah 4 responden $(13,3 \%)$, kunjungan 6 sampai 10 kali sejumlah 24 responden (80,0\%) dan kunjungan 11 sampai 15 kali sejumlah 2 responden $(6,7 \%)$.

\section{Analisis Univariat}

a. Distribusi Frekuensi Responden berdasarkan Hasil Pre Test Tingkat Kecemasan Ibu Hamil Primigravida sebelum diberikan Hypnobrithing di Klinik Pratama Annur Karanganyar

Tabel 6. Hasil Pre Test Tingkat Kecemasan Ibu Hamil Primigravida sebelum diberikan Hypnobirthing di Klinik Pratama Annur Karanganyar

\begin{tabular}{lcc}
\hline \multicolumn{1}{c}{ Tingkat Kecemasan } & Frekuensi & Persentase \\
\hline Tidak ada cemas & 0 & $0 \%$ \\
Kecemasan ringan & 19 & $63,3 \%$ \\
Kecemasan sedang & 11 & $36,7 \%$ \\
Kecemasan berat & 0 & $0 \%$ \\
\hline Jumlah & 30 & 30 \\
\hline
\end{tabular}


Tabel 6 menunjukkan bahwa tingkat kecemasan ibu hamil primigravida sebelum dilakukan hipnobirthing didapatkan 19 responden $(63,3 \%)$ mengalami kecemasan ringan, 11 responden $(36,7 \%)$ mengalami kecemasan sedang.

b. Distribusi Frekuensi Responden berdasarkan Hasil Post Test Tingkat Kecemasan Ibu Hamil Primigravida sesudah diberikan Hypnobirthing di Klinik Pratama Annur Karanganyar

Tabel 7. Hasil Post Test Tingkat Kecemasan Ibu Hamil Primigravida sesudah diberikan Hypnobirthing di Klinik Pratama Annur Karanganyar

\begin{tabular}{lcc}
\multicolumn{1}{c}{ Tingkat Kecemasan } & Frekuensi & Persentase \\
\hline Tidak ada cemas & 13 & $43,3 \%$ \\
Kecemasan ringan & 14 & $46,7 \%$ \\
Kecemasan sedang & 3 & $10,0 \%$ \\
Kecemasan berat & 0 & $0 \%$ \\
\hline Jumlah & 30 & 30 \\
\hline
\end{tabular}

Tabel 7 menunjukkan bahwa tingkat kecemasan sesudah dilakukan hipnobirthing didapatkan 14 responden $(46,7 \%)$ mengalami kecemasan ringan, 3 responden (10\%) mengalami kecemasan sedang dan 13 responden $(43,3 \%)$ tidak mengalami kecemasan.

\section{Uji Statistik Pengaruh Sebelum Hypnobirthing terhadap Tingkat} Kecemasan ibu hamil primigravida di Klinik Pratama Annur Karanganyar

Tabel 8. Pengaruh Sebelum dilakukan Hypnobirthing terhadap Tingkat Kecemasan ibu hamil primigravida di Klinik Pratama Annur Karanganyar

\begin{tabular}{lccccc}
\hline & \multicolumn{2}{c}{$\begin{array}{c}\text { Levene's Test for Equality } \\
\text { of Variances }\end{array}$} & \multicolumn{3}{c}{ t-test for Equality of Means } \\
& F & Sig & $\begin{array}{c}\text { Sig. (2- } \\
\text { tailed) }\end{array}$ & $\begin{array}{c}\text { Mean } \\
\text { Difference }\end{array}$ & $\begin{array}{c}\text { Std. Error } \\
\text { Difference }\end{array}$ \\
\hline Sebelum & 4.322 & .047 & .312 & 1.000 & .971 \\
Hypnobirthing & & & & & \\
\hline
\end{tabular}

Tabel 8 uji stastistik dengan independent samples t-test didapatkan hasil sebelum dilakukan Hypnobirthing $\mathrm{p}$ value $($ sig 2 tailed $)=0,312$ dan $\alpha 0,05 \quad(\mathrm{p}$ $>\alpha$ ) yang menunjukkan tidak ada pengaruh sebelum dilakukan Hypnobirthing terhadap Tingkat Kecemasan ibu hamil primigravida.

\section{Uji Statistik Pengaruh Sesudah Hypnobirthing terhadap Tingkat} Kecemasan ibu hamil primigravida di Klinik Pratama Annur Karanganyar

Tabel 9. Pengaruh Sesudah dilakukan Hypnobirthing terhadap Tingkat Kecemasan ibu hamil primigravida di Klinik Pratama Annur Karanganyar

Levene's Test for

Equality of Variances

\section{t-test for Equality of Means}

Sig. (2
Mean 


\begin{tabular}{|c|c|c|c|c|c|}
\hline & & & tailed) & Difference & Difference \\
\hline $\begin{array}{l}\text { Sesudah } \\
\text { Hypnobirthing }\end{array}$ & .117 & .735 & .000 & -5.400 & 1.192 \\
\hline
\end{tabular}

Tabel 9 uji stastistik dengan independent samples t-test didapatkan hasil sesudah dilakukan Hypnobirthing $\mathrm{p}$ value (sig 2 tailed $)=0,000$ dan $\alpha 0,05 \quad(\mathrm{p}$ $<\alpha$ ) yang menunjukkan ada pengaruh sesudah dilakukan Hypnobirthing terhadap tingkat kecemasan ibu hamil primigravida.

Berdasarkan karakteristik responden pada penelitian ini didapatkan dari Tabel 1 menunjukkan bahwa usia responden ibu hamil sebagian besar antara 21-25 tahun sejumlah 19 orang dan usia 26-30 tahun sejumlah 11 orang. Usia tersebut merupakan usia yang ideal dan produktif dalam menjalani masa kehamilan, persalinan maupun menyusui. Berdasarkan Tabel 2 sampai dengan Tabel 5 bahwa responden ibu hamil primigravida yang baru pertama kali hamil, belum pernah melahirkan, dan periode kehamilan trimester ketiga dan Rata-rata pendidikan responden sebagian besar Sekolah Menengah Atas dan lulusan dari perguruan tinggi. Responden mempunyai pekerjaan sebagai ibu rumah tangga dan sebagian responden rutin melakukan kunjungan kehamilan.

Berdasarkan hasil penelitian dapat dilihat pada tabel 6 menunjukkan bahwa tingkat kecemasan ibu hamil primigravida sebelum dilakukan hipnobirthing didapatkan 19 responden $(63,3 \%)$ mengalami kecemasan ringan, 11 responden $(36,7 \%)$ mengalami kecemasan sedang.

Hasil penelitian ini sejalan dengan hasil penelitian Anita,2015 bahwa tingkat kecemasan sebelum tanpa hipnobirthing dengan tingkat kecemasan paling rendah adalah 107 dan tingkat kecemasan tertinggi adalah 188. Repsonden merasakan kecemasan dan kekhawatiran, ketakutan terhadap kelahiran bayinya karena ibu baru pertama hamil dan mengalami gangguan yang tidak diinginkan.

Penelitian (Kamilia, 2012) menjelaskan bahwa efek dari rasa cemas dan stres saat ibu hamil dapat mempengaruhi jiwa ibu dan janin. Secara psikologis, ibu yang tidak tenang dan kondisi yang menurun janin akan menjadi merasa gelisah dan berdampak pada kesehatannya. Hubungan batin yang kuat antara ibu dan bayi dapat mempengaruhi pikiran ibu ke janin. Ibu hamil merasakan sakit dan nyeri saat proses persalinan normal sehingga persalinan secara normal kurang diminati dan membutuhkan cara untuk mengatasi rasa nyeri saat proses persalinan.

Berdasarkan hasil penelitian pada tabel 7 menunjukkan bahwa tingkat kecemasan sesudah dilakukan hipnobirthing didapatkan 14 responden (46,7\%) mengalami kecemasan ringan, 3 responden (10\%) mengalami kecemasan sedang dan 13 responden $(43,3 \%)$ tidak mengalami kecemasan.

Penelitian ini didukung oleh hasil penelitian Ilmiasih (2010) dalam penelitian Winda dan Wulan, 2013 bahwa tingkat kecemasan ibu hamil cenderung menurun sesudah dilaksanakan pelatihan hypnobirthing, yang didapatkan hasil $56 \%$ ibu hamil tidak mengalami cemas dan $38 \%$ ibu hamil dengan tingkat kecemasan ringan.

Penelitian Yuseva, 2016 menjelaskan bahwa penurunan tingkat kecemasan pada ibu hamil setelah dilakukan latihan relaksasi hipnobirthing 73,3\% tidak ada gejala kecemasan. Penurunan tingkat kecemasan dari hypnobirthing membawa kerja otak pada gelombang alfa yaitu gelombang yang memiliki frekuensi14-30 HZ. 
Pada kondisi ini otak dalam keadaan santai, antara sadar dan tidak dan nyaris tertidur, saat tubuh mulai mengeluarkan hormon serotonin yang bermanfaat mengelola suasana hati dan mencegah depresi dan hormon endorfin yang berguna untuk menghilangkan stres dan pereda sakit secara alami.

Berdasarkan hasil penelitian pada tabel 8 uji stastistik dengan independent samples t-test didapatkan hasil sebelum dilakukan Hypnobirthing $\mathrm{p}$ value (sig 2 tailed $)=0,312$ dan $\alpha 0,05 \quad(\mathrm{p}>\alpha)$ yang menunjukkan tidak ada pengaruh sebelum dilakukan Hypnobirthing terhadap Tingkat Kecemasan ibu hamil primigravida.

Menurut hasil penelitian Marliana, 2016 menunjukkan bahwa uji Mann Whitney dengan rata-rata selisih penurunan kecemasan pada kelompok

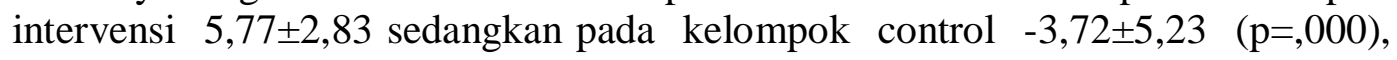
rata-rata selisih menunjukkan bahwa pada kelompok intervensi terjadi penurunan rerata kecemasan yang lebih besar dibandingkan dengan kelompok control, hal ini disebabkan ibu memiliki pemberdayaan diri terhadap kehamilannya dan peningkatan pengetahuan pada ibu hamil tentang hypnobirthing dapat menjalani kehamilan dengan pikiran positif.

Menurut penelitian Anita, 2015 menunjukkan ada perbedaan kecemasan pada responden yang tidak diberikan hipnobirthing. Beberapa faktor seperti kondisi ibu, umur, pendidikan, kondisi lingkungan, dukungan sosial, atau sosial ekonomi sehingga memungkinkan dari rasa tidak ada kecemasan menjadi sebuah kecemasan. Penelitian ini menunjukkan bahwa faktor dari usia dan paritas. Diketahui bahwa usia responden dalam penelitian usia reproduktif kurang dari 35 tahun dan dalam periode kehamilan yang pertama kali (primigravida).

Berdasarkan tabel 9 uji stastistik dengan independent samples t-test didapatkan hasil sesudah dilakukan Hypnobirthing p value (sig 2 tailed) $=0,000$ dan $\alpha 0,05(\mathrm{p}<\alpha)$ yang menunjukkan ada pengaruh sesudah dilakukan Hypnobirthing terhadap tingkat kecemasan ibu hamil primigravida.

Penelitian ini sesuai dengan penelitian yang dilakukan oleh (Winda,2018) bahwa ada pengaruh teknik hypnobirthing terhadap penurunan tingkat kecemasan ibu hamil trimester 3 pada persiapan proses persalinan, menjelaskan bahwa teknik hypnobirthing suatu metode khusus untuk wanita hamil dengan melakukan relaksasi mendalam, bertujuan untuk mempersiapkan proses kelahiran normal yang lancar, nyaman dengan rasa sakit yang minimum, karena mampu memicu hormon endorphin sebagai hormon penghilang rasa sakit tubuh yang alami.

Berdasarkan penelitian dari Pramita, 2016 menjelaskan bahwa hipnosis merupakan tubuh seseorang dalam kondisi yang relaks, fokus, perasaan tenang (calm), persepsi yang positif dan semua aspek kehidupan seperti orang yang terhipnosis dapat menyerap dan tersugestikan ke seseorang dan tidak terpengaruh dengan suasana di sekelilingnya dan seseorang dapat melakukan yang disugestikan.

Menurut Martalisa dan Budisetyani tahun 2013 hypnobirthing bermanfaat bagi semua keluarga, dengan adanya hubungan hypnobirthing dengan tingkat kecemasan ibu hamil membuktikan bahwa metode hypnobirthing sebagai teknik relaksasi dapat memberikan sugesti positif yang mampu meningkatkan kenyamanan dan ketenangan jiwa ibu hamil saat kehamilan dan persalinan. Oleh 
karena itu, dengan melakukan teknik relaksasi mampu meminimalkan kecemasan yang dirasakan ibu hamil.

Hasil penelitian ini sejalan dengan hasil penelitian (Rofi'a, 2013) dalam Kuswandini menjelaskan hypnobirthing merupakan upaya alami untuk menanamkan niat positif ke pikiran bawah sadar agar ibu dapat menjalani kehamilan sehat dan menghadapi persalinan dengan tenang, alami, nyaman, dan lancar. Hal ini sejalan dengan pendapat Asmarany (2012) menyatakan bahwa, hypnobirthing terbukti memiliki dampak positif dalam membantu mengurangi tingkat kecemasan ibu hamil menjelang persalinan anak pertama. Empat teknik dasar dalam hypnobirthing yaitu teknik relaksasi dengan pernapasan, teknik relaksasi otot, teknik visualisasi dengan relaksasi pelangi, dan berkomunikasi dengan janin pemberian efek relaksasi)

\section{SIMPULAN}

Karakteristik responden sebagian besar usia reproduktif kurang dari 35 tahun, Responden ibu hamil primigravida dan periode kehamilan trimester ketiga, pendidikan responden sebagian besar Sekolah Menengah Atas. pekerjaan responden sebagai besar Ibu Rumah Tangga dan sebagian responden rutin melakukan kunjungan kehamilan. Tingkat kecemasan ibu hamil primigravida sebelum dilakukan hipnobirthing didapatkan 19 responden $(63,3 \%)$ mengalami kecemasan ringan, 11 responden $(36,7 \%)$ mengalami kecemasan sedang. Tingkat kecemasan sesudah dilakukan hipnobirthing didapatkan 14 responden $(46,7 \%)$ mengalami kecemasan ringan, 3 responden (10\%) mengalami kecemasan sedang dan 13 responden $(43,3 \%)$ tidak mengalami kecemasan. Pada penelitian ini dapat disimpulkan ada pengaruh sesudah dilakukan hypnobirthing terhadap tingkat kecemasan ibu hamil primigravida dengan $\mathrm{p}$ value $=0,000$

\section{SARAN}

Saran dari penelitian yaitu bagi petugas atau profesi kesehatan diharapkan dapat melakukan tindakan intervensi hypnobirthing untuk menurunkan tingkat kecemasan menghadapi persalinan pada ibu hamil primigravida, bagi ibu hamil diharapkan lebih meningkatkan pengetahuan tentang hypnobirthing melalui buku,artikel maupun media sosial dan melakukan antenatal care secara teratur kepada petugas kesehatan dalam upaya menurunkan kecemasan saat kehamilan maupun persalinan.

\section{DAFTAR PUSTAKA}

Adina, F., A. 2019. Perbedaan Keikutsertaan Hypnobirthing dengan Tingkat Kecemasan Ibu Hamil dalam Menghadapi Persalinan di Kabupaten Sidoarjo.Jurnal Keperawatan Muhammadiyah. Fakultas Kesehatan Masyarakat Universitas Airlangga Surabaya.https://journal.umsurabaya.ac.id

Andriana, Evariny. 2013. Melahirkan Tanpa Rasa Sakit. Jakarta: BIP.

Anita, I., A., Diajeng, Q.,A., Alfi, R. 2015. Pengaruh hipnobirthing terhadap tingkat kecemasan pada ibu hamil Primigravida di Bidan Praktek Mandiri 
Indah Septiani Manyaran kota Semarang.Prosiding Nasional. STIKES Karya Husada Semarang. 125-134.

Aprillia, Y. 2013. Hipnostetri, Rileks, Nyaman dan Aman Saat Melahirkan. Jakarta: Gagas Media.

Kamilia, A. 2012. Efektifitas penerapan hypnobirthing dalam menurunkan tingkat kecemasan ibu hamil trimester tiga menjelang persalinan anak pertama di usia dewasa awal. Jurnal Penelitian dan Pengukuran Psikologi. Vol (1). No 1 .

Marliana, Tjahjono, K., Sri, W. 2016. Pengaruh Hypnobirthing terhadap Penurunan Tingkat Kecemasan, Tekanan Darah, dan Denyut Nadi pada Ibu Hamil Primigravida Trimester III.Jurnal Ilmiah Kesehatan (JIK). Vol (IX). No 1

Martalisa, W. \& Budisetyani, W. 2013. Hubungan intensitas keikutsertaan hypnobirthing dengan tingkat kecemasan ibu hamil di gianyar. Program Studi Psikologi, Fakultas Kedokteran, Universitas Udayana. Vol.1, No.1, 116-128..

Pramita, S.,U, Uki, R, Eti, P. 2016. The Effectiveness of Hypnobirthing in Reducing Anxiety Level During Delivery. Jurnal of Maternal and Child Health (2016), Vol (1) No 3: 200-204

Rofi'a, A., Gatut, H.2013. Efektivitas hypnobirthing terhadap Kecemasan ibu primigravida trimester 3 di RB Sisilia Yosepha Trihana. Jurnal Kesehatan Universitas Airlangga.

Utami, A. \& Lestari, W. 2011. Perbedaan tingkat kecemasan primigravida dengan multigravida dalam menghadapi kehamilan. Jurnal Ners Indonesia. https://jni.ejournal.unri.ac.id/ diakses 20 Desember 2019

Winda, M., dan Wulan,B .2013. Hubungan Intensitas Keikutsertaan Hypnobirthing dengan Tingkat Kecemasan Ibu Hamil di Gianyar. Jurnal Psikologi Udayana.Vol (1), No 1, 116-128.

Winda,Y., H. 2018. Pengaruh teknik hypnobirthing terhadap penurunan tingkat Kecemasan ibu hamil trimester 3 pada persiapan proses persalinan. Jurnal Kesehatan Ibu dan Anak Annur. Vol (3), No 2.

Yuseva,S., Era,N.,W., Nur, A., R. 2016. Pengaruh Hypnobirthing Terhadap Tingkat Kecemasan Ibu Bersalin Dan Lama Persalinan Di Bidan Praktek Mandiri Wilayah Kabupaten Malang. Jurnal Ilmiah Bidan. Vol (1). No.3 